\title{
VIII. Report of the progress of the sciences in France in 1813
}

\section{J.C. Delametherie}

To cite this article: J.C. Delametherie (1814) VIII. Report of the progress of the sciences in France in 1813, Philosophical Magazine Series 1, 44:195, 25-32, DOI: 10.1080/14786441408637407

To link to this article: http://dx.doi.org/10.1080/14786441408637407

里 Published online: 27 Jul 2009.

Submit your article to this journal $₫$

Џll Article views: 3

Q View related articles $\square$ 
derable portion of the substance to be analysed, always resists the affusion of new quantities of acid.

The best method of producing an almost complete solution consists in using sulphuric acid, and a considerable yuantity of potash, which nevertheless ought not to neutralize all the acid. By this means we obtain a salt which has the characters of alum, although it contains a proportion of alkail greater than that which is necessary to the crystallization of common alum, and we may dissolve the earth with the exception of the same.

It results from all the above observations :

1. That the snow or hail which fell at Arezzo derived its colour from a very fine earthy substance interposed with uniformity between the small crystals of the hail, without however being inclosed in their nucleus.

2. That this substance is composed almost entirely of alumine, very little carbonated lime, and a still less quantity of iron, manganese, and silex; finally, of a very feeble animal or vegetable principle, capable of being carbonized by the action of sulphuric acid and of putrefying water.

I do not mean to decide upon the etiology of the phænomenon which took place during some grand electrical operations of nature; but it ought by no means to be ascribed to the stormy nature of the winds.

In fact, no storm was experienced is: the town or environs: besides, the wind could not produce effects so perfectly identical to a great extent, or in all directions, nor porphyrize the earth, nor divide it with. so much regularity in the mass of snow or hail. Lastly, the ground being every where previously covered with snow, it can scarcely be supposed that the wind could take up an argillaceous earth with it to scatter it afterwards with fresh snow.

VIII. Report of the Progress of the Sciences in France in 1813. By J. C. Delametherie.

[Concluded from vol. xliii. p. 439.]

PHYSICS.

THis branch of science determines the laws of motion in various bodies, and these are divided into two parts; viz. those which relate to solid bolies, and those which relate to fluid bodies. Lagrange in his Mecanique (tome i.) conwders these laws under two different heads. 1. Statics, or the theory of equilibrium. 2. Dymamics, or the theory of motion. The theory of the equilitim of fluids is consequently denominated 
Hydrostaties. The theory of the motion of fluids has been subjected by Lagrange to the most rigorous analysis.

1. The properties of the equilibrium of a free system of bodies, relative to the motion of translation.

2. The properties of equilibrium relative to the movement of rotation.

Of Statics. Lagrange has referred all the laws of statics, or of the theory of the equilibrium of solids, to three principles; that of the lever, that of the composition of forces, and that of the virtual velocities.

Of Machines They make up for the weakness of our organs, and new machines are daily invented. The Voltaic pile has been one of the most valuable discoveries of late years for the advancement of science.

of Hydrostatics and Hydronamics. "Although we are ignorant," says M. Lagrange (tome i.p. 174), " of the interior constitution of fluids, it cannot be doubted that the particles of which they are composed are material, and that for this reason the general laws of equilibrium cannot suit them as they do solid bodies. In faet, the general property of fluids, and the only one which distinguishes them from solid bodies, consists in all their parts yielding to the smallest possible force and moving with all possible facility."

In o:der to conceive the cause of these phænomena, we must admit that each particle of matter has a peculiar force, which it never loses.

From sal ammoniac for instance, when triturated with lime, the volatile alkali is extricated with all its usual vivacity.

From the sulphuric acid, when poured upon the same salt, the marine acid is also extricated with force.

The molecules of the ammonia and those of the marine acid had each therefore a peculiar force which was in nisu, like those of a spring.

The molecules of solids, on the contrary, are most frequently nearly immoveable, because their peculiar forces are in $n i, u$, as in the metals, stones, \&c. Nevertheless they have sometimes particular motions, like those of warm substances, sonorous bodies, electric bodies, \&c.

The molecules of fluids have a constant rotatory motion around their axis or point of equilibrium, and they yield to the least force. Whereas solids oppose all their vis inertice in the ratio of their masses. This is the cause of the differences exhibited by solids and fluids in their motions.

Fluids are divided into two classes: Ethereated fluids, which Davy improperly calls imponderalle fluids. Non-ethereated fluids, 
fluids, such as water, oil, \&c. We shall make known the addicions which have been male this year to our stock of knowledge on this subject. Bremontier has published some interesting observations on the novement of waves.

Rhuiand has made some new experiments on the radiation of heat: ho has proved that the more calmic is lost by bodies by radiation, the more the surrounding lodies are obliged to give wip to them their proper heat, in order to re-establish the equilibrium of heat. (Journal de Physique, Nov. 1813.)

it appears to me that we may conclude that there is thus established a double movement of caloric : viz. a caloric effuent from warm bodies, and a caloric affuent from bodies less warm.

The greatest heat ever product d has been obtained by Sir Humphry Davy, by neans of the Galvanic battery of the Royal Institution. (Here follows a description of the apparatus and experiments, which are familiar to our readers.)

Configliati, by repeating the experiments of Leslie upon artificial cold, has obtained some very curious results, and succeeded in freezing mercury.

\section{CHEMISTRY.}

Under this head M. Delametherie passes a just eulogium on the recent labours of Sir Humphry Davy and Berzelius, of whose improvements he gives a full analysis.

He then notices the labours of the French chemists. Bouillon Layrange and Vogel have furnished a new analysis of different kinds of sea-water; viz. from the Mediterranean, at Marseilles, and the Ocean at Bayonie and Havre.

One thousand grains of sea-water from Havre yielded:

Of Saline matter obtained by evaporation . . $36^{\circ}$

Cas'bonic acid .............. 0.23

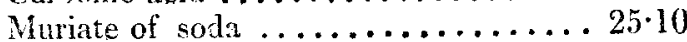

Muriate of magnesia ............ 3.50

Sulphate of magnesia ........... 5.78

Carbonate of lime and magnesia ..... 0.20

Sulphate of lime ............. $0 \cdot 15$

One thousand grains of sea-water from Bayonne afforded:

Of Saline matter by evaporation ....... 38.

Carbonic acid ............... $0 \cdot 23$

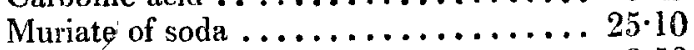

Muriate of magnesia ............ 3.50

Sulphate of magnesia .......... $5 \cdot 78$

Carbonate of lime and magnesia...... $0 \cdot 20$

Sulphate of lime ............. 0.15 


\section{Report of the Progress of the Sciences in France.}

One thousand grains of sea-water taken at Marseilles yielded:

Of Saline matter by evaporation ....... $41^{\cdot}$

Carbonie acid ................. 0.11

Muriate of soda .................25 10

Muriate of magnesia ............ $5 \cdot 25$

Sulphate of magnesia .......... 6. 6.5

Carbonate of lime and magnesia ....... $0 \cdot 15$

Sulphate of lime ............. 0.15

The muriate of magnesia is the only deliquescent salt in seawater; hence arises the property which sea-salt possesses, of liquefying on exposure to air. A small quantity of the muriate of soda contained in sea-water is carried up when we distil it: this is the cause of our finding muriate of soda in vegetables at a certain distance from the sea.

In the chemical analysis of animal substances Berzelius has made great improvements. He has submitted the animal fluids, and particularly the blood, to new analyses. The blood, he says, is composed of two parts; a liquid, the serum, and one which is suspended, the coagulum. In the aninal oeconomy we ought to distinguish three principal substances: $a$, fibrine; $b$, albumen; $c$, gelatine.

The serim, according to Berzelius, is a solution of a great quantity of albumen with a little fibrine. Both are combined with soda. It also contains some other saline substances.

The coagulum is the colouring matter. It differs from albumen in its insolubility in serum, and by its colour. The colouring matter amounts to about one-third of the mass: the colour seems to be owing to iron, of which it contains about onethird of its weight; but this iron can be separated by combustion only.

This colour cannot be produced artificially by uniting albumer with subphosphate of iron, as Fourcroy and Vauquelin have asserted. Nor it is possible to produce it by uniting iron with soda, as Parmentier and Deyeux have supposed.

We may compare the colour of the blood to the other red colouring principles formed by animals, cochineal, kermes, the purple of the murex, $\& \mathrm{c}$.

Four hundred grains of colouring matter, when incinerated, yielded:

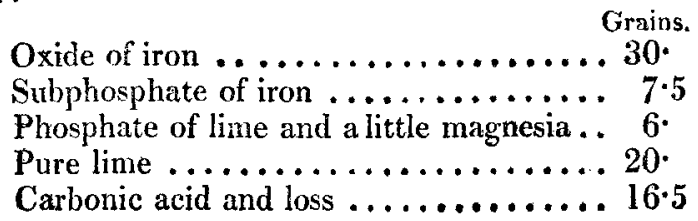


The serum of the blood gave upon analysis: Grains.

Water.......................90.5

Albumen ....................... 80.

Muriate of potash, soda, and lactate of soda..... 4.

Soda, phosphate of soda, and a little animal matter $4 \cdot 1$

In speaking of the lactate of soda, Berzelius observes, that the existence of the lactic acid discovered by Scheele had been erroneously doubted by Fourcroy and Vauquelin. The blood contains no gelatine nor earthy phosphate.

The fibrine, albumen, and colouring matter resemble each other so closely, that they may be considered as modifications of one and the same substance: they give earthy phosphates and carbonates of lime solely when they are decomposed.

The author thinks that the phosphate of iron does not exist in the non-decomposed colouring matter, and that which we obtain by incinerating it is a product of combustion.

The colouring matter dried and exposed to the fire in a redhot crucible melts, swells, and burns with a clear flame; it leaves a pory charcoal, which burns with difficulty. In burning, a smell of ammonia is constantly exhaled, although it had been exposed several times to a strong fire.

This extrication of ammonia from a burning charcoal, and which has been long exposed to the fire, is according to him a remarkable phænomenon: hence he concludes that this ammonia is a new prodúct.

Margarine.-Chevreul has entered upon an extensive inquiry into the combinations of fat bodies and the alkalis. When we put, he observes, soap from hogs' lard and potash in a great mass of cold water, one part is dissolved and another is deposited in the form of small shining pellets: he calls it mother of pearl sulstance (matière nacrée).

This matter is formed of potash ...... $8 \cdot 16$

Another fat substance.............. 91.84

This last substance has the lustre of a pearl. The author on this account calls it margarine, from the Greek word. In order to obtain it, he places the mother of pearl substance in water acidulated with muriatic acid. The acid seizes the potash, and the margarine swims above. The latter is lighter than water, and melts at 56.560 centigrade.

From all the facts recently publisher by Sir Humphry Davy and Berzelius, M. Delametherie draws the following conclusions:

1. We can no longer regard pure air, or oxygen as it has been called, as the principal agent of heat or of combustion, since it is proved that this gas contains the least caloric of any other, and that the inflammable gas, the hydrogen as it is called, contains the most caloric. Besides, it is proved that in several 
combinations of oxygen, such as that with the nitrous gao, there is but a very small quantity of heat extricated. The oxygen inspired has little infiuence in the prociuction of heat is animals and vegetables.

2. Oxygen can no longer be regarded as the generator of acids, hydrogen frequently performing its functions.

a. The acids, such as the flurric, ony-munitic, iodic, hydrosulphuric, hydro-telluric, and the prussic, contain no oxyen.

l. Substances which contain oxygei are not acids, but rathes alkalis; such as potash, soda, the earths, the metalic oxides, \&c.

$c$. The water, which upon this hypothesis contains 0.87 oxysen, is not acid.

3. The inflammable gas or hydrogen is to be found in all the combustible bodies. This is admitted with respect to animal and vegetable substances. It is also proved that it is found in the mineral combustible bodies, such as charcoal, the diamond, sulphur, phosphorus, the metals.

"The combustion of the metals, particularly that of zinc," I chserved in 1781, in the Journal de Physique, "always suggested to me that inflammable air was one of their principles."

Davy regards this opinion as highly probable, and has assigned the quantities of hydrogen contained in several of these bodies.

4. This inflammable air onght therefore to be regarded as the primeiple which Stahl called phlogiston: this name ought to be continued.

5. This inflammahle air of all the acidifiable bodies, the oils, suiphur, metals, is partly consumed when we burn these bodies, and when they pass to the state of acids.

6. The hydrogen so burnt furnishes water, which ought conseruentiy to exist in the new compounds.

7. Berzelius and several chemints are of opinion that infammable air, or hydrogen, contains a metallic oxide, which enters into the composition of ammonium.

8. They have the same opinion of azote: it contains a me* tallic oxide, which also enters into the formation of ammonium.

9. I have observed, as we!l as Priesîley, Senebier, Berger, and others, that these gases, hydrogen and azote, exposed over water, or agitated with water, are decomposed, and pass to the state of pure air : the inflammabie air loses its infammability, and the azote becomes absorbalye by the nitrous gas. On the other hand, pure air exposed over water is als decomposed: it is less absorbed by the nitrous gas than before.

We have seen that in respiration there is less carbonic acid protuced than oxygen absorbed. This made Berthollet and Delaroche conclude that there had been a production of azote. 
10. It is problalle therefore that there is only one kind of sir, viz. pute air, which may be modified into inflammable gas, and into arotic gas.

11. Caloric enters, as the principle of the nitric acid, into the combination of the nitrons gas and oxygen. It ought therefore to be one of the principles of the other acids, the oxides, alkalis, and earths. This is the causticum of Meyer.

12. The new theory has therefore only the merit of having confirmed the opinion of Jean Rey, and Hales, who had proved that in combustion, and in the calcination of metals, there was a combination of a portion of air which augmented the weight of the burnt body; a truth to which too little attention has since been paid. But it was wrong to reject the principle of infammability which exists in combustible bodies, as well as the caloric which is combined in the new products. The new nomenclature, besides, is very imperfect.

13. It is probable, therefore, according to the present notions, that an acid, the sulphuric for instance, is composed,

a. Of a base, that of sulphur.

l. A portion of hydrogen.

c. - oxygen.

d. - caloric combined.

e. - water.

The same may be said of the oxides, earths, \&r.

There are some exceptions, however: the oxymuriatic, fluoric, and iodic auts do not contain oxvgen, but hydrogen.

14. But what are the bases of sulphur, phosphorus, \&c.? This is a question in chemistry which remains to be solved.

Chemists have wished to regard all these bases as simple elemenls, or at least indecomposed, because art has not yet decomposed them. But I have constantly maintained that, suppusing most of these baces had not yet been decomposed, every fact seems to prove that a great number of these bases, and perhaps the whole, are daily composeci : they are produced like the principles said to be inimediate of vegetables and amimals.

a. The fluoric acid is found in the tecth: what is it that tirnishes it, if it be not a new product?

b. Phosphorus is very abundant, in animal and vegetable subatances, in the form of phosphoric acid. We may say the same of sulphur, charcoal, \&c. Whar is it that furnishes them, if they are not new products?

$c$. Potash and soda are very alsundant in vegetable and animal substances, and in nitre pits, the earth of which has been cleansed by repeated washings from all saline substances. What is it that furnishes them, if they are not new products?

d. The eirths, particulariy magnesia, so abundant in the lixi- 
viums from nitre pits, and amang animals, present the same phæuonena.

Now, potash, soda, and the earths are metallic oxides.

$e$. Metals themselves, such as iron and manganese, are very ahundant in vegetables and animals. What is it that furnishes them, particularly manganese, if they are not new products?

15. The production of ammonium by exposing to the action of the Voltaic pile mercury with ammonia, may throw some light on the new production of these bases. The azotic and hydrogen gases seem to be the principal bases of ammonia. These two gases therefore concur, according to Berzelius, in the formation of a metallie substance, ammonium.

Caloric, the luminous fluid, and the Galvanie fluid, may also concur not only in the formation of ammonium, but of the other metals, the alkalis, earths, sulphur, phosphorus, carbon, $8 \mathrm{c}$.

16. All these fluids themselves are probably formed of one sole primitive matter. This was the opinion of the philosophers of antiquity, and it has been sanctioned by Newton, according to $\operatorname{Sir}$ H. Davy. This primitive matter is perhaps the nelulous matter, or akasch. It is probable that chemistry will decompose some of these bases.

17. The Galvanic action has the greatest influence in the principal phænomena of nature: such as fermentation; the inflammation of pyrites, the pyrophori, and the various chemical combinations, compositions, and decompositions; the various phænomena of the animal and vegetable oeconomy; heat, irritability, excitability, sensibility; the electrical state of the terrestrial globe, \&c.

18. Electricity and Galvanism therefore contributing to chemical combinations, their action is continual and never interrupted. The electro-chemical theory of Berzelius merits the whole attention of scientifie men.

19. It is no more demonstrated that water is composed of hydrogen and oxygen, as Cavendish says, than that it may be converted into earth as maintained by Newton.

20. The action of the molecules of solid bodies depends rather on their figure than their mass.

M. Delametherie thus concludes his Sketch of the Progress of the Sciences, of which the ahove is an extract:

"Yet a little while, and these truths will be recognised like those to which I have already alluded; viz. the great quantity of caloric in the inflammable gas, the small quantity of caloric in pure air, the insufficiency of oxygen for producing the acids, the imperfection of the new chemical and mineralogical nomenclatures, the insufficiency of the new chemical theories, and the insuffeiency of crystallography for making us acquainted with mineials."

IX. $M$ 